\title{
IMPACT OF IRRIGATION ON AGRICULTURE PRODUCTIVITY IN SOLAPUR DISTRICT OF MAHARASHTRA STATE
}

\section{TODKARI G.U.}

Dept. of Geography, Shri Sant Damji Mahavidyala Mangalweda, Dist-Solapur, MS, India.

*Corresponding Author: Email- govindtodkari@gmail.com

Received: December 09, 2011; Accepted: January 03, 2012

\begin{abstract}
Irrigation is identified as a decisive factor in Indian agriculture due to high variability and inadequacy of rainfall. Irrigation is essential for successful agriculture particularly in the area, where rainfall is inadequate uncertain, and unpredictable. These areas are prone to drought and famine condition due to partial failure and delayed arrival or early withdrawal of monsoon. Importance of irrigation has substantially increased after the adoption of High yielding varieties in developing countries. Irrigation is basic determinants of Agriculture because its inadequacies are the most powerful constraints on increase of Agricultural production. In the study region the variation of an annual rainfall from year to year is fairly large. The rainfall is irregular and uncertain in the Study region, here agriculture is gamble with monsoon. If rainfall is scare it results into crop failure. For the assure agriculture production irrigation is most important factor. There fore attempt is made here to examine the impact of irrigation on agriculture productivity in Solapur district.
\end{abstract}

Key words- Irrigation intensity, Agriculture productivity, Spatial pattern, Co-efficient index.

Citation: Todkari G.U. (2012) Impact of irrigation on agriculture productivity in Solapur District of Maharashtra State. International Journal of Agriculture Sciences, ISSN: 0975-3710 \& E-ISSN: 0975-9107, Volume 4, Issue 1, 2012, pp-165-167.

Copyright: Copyright@2012 Todkari G.U. This is an open-access article distributed under the terms of the Creative Commons Attribution License, which permits unrestricted use, distribution, and reproduction in any medium, provided the original author and source are credited.

\section{Introduction}

Irrigation is basically an agriculture operation, supplying the need of water for plants. To agriculturalists it is a component of successful crop husbandry in dry climate, ranking high with the application of fertilizers, the control of weeds and destructive pests, cultivation and the position of drainage.

Irrigation is the most important factor in farming according to the Agriculture Department and Irrigation Officers. Irrigation has played an important role in transforming the crop cultivation and better yield .There are various any other type of irrigation such as in their well irrigation, rivers ,tanks and canal etc. But there are additional factors such as their location, their topography, geological aspect and height, hilled area depending on various elements. In The region under study mainly two types of irrigation are practised namely well and canal irrigation .

The Solapur District is located in drought prone area, and so rainfall is low . Hence irrigation plays a vital role in agriculture. In $2004 / 05$ the total area from all sources of irrigation is 288736 hectares The spatial pattern of irrigation is however, uneven and has been characterized by the changes over time.

\section{Study Area}

The present study deals with the geographical perspectives of the agriculture in Solapur district. The Solapur district is bounded by $17^{\circ} 05^{\prime}$ North latitudes to $18^{\circ} 32^{\prime}$ North latitudes and $74^{\circ} 42^{\prime}$ East of $76^{\circ} 15^{\prime}$ East longitudes. The total geographical area of Solapur district is $14895^{2} \mathrm{~K} . \mathrm{m}$. divided into eleven tahsils. The Population is 32.4 lakhs in eleven tahsils of District. (Censes 2001). It is bounded from the North by Osmanabad district and Ahmednagar district, on the North-East by Satara district and at the South \& East it has common boundary of Karanataka state. Temperature is high in summer season. Rainfall varies from East to West between range of 200 to 600 millimeters. The rivers like Bhima, Sina, Man, Nira Bhogawati and many other smaller tributaries drain in the district. The soil of the district is mainly of DeccanTrap Volcanic origin. It is underlined by partially decomposed Basolatic rock material locally known as "murum". 


\section{Aims and Objective}

- To understand the irrigation intensity in Solapur District.

- To illustrate the agriculture productivity in study region.

- To find out the impact of irrigation on agriculture production in study region.

\section{Data and Methodology}

Tahasilwise secondary data of irrigated area and agriculture productivity are used for present study. It is collected from District Agriculture Dept. of Solapur and District wise Statistical Information of Maharashtra state.

The statistical equation are used for irrigation intensity.

To know the agriculture productivity the Kendal's Ranking Coefficient method is used.

The statistical and cartographic techqunices are used fro representation of co-efficient index.

\section{Explanation \\ Intensity of Irrigation}

The intensity of irrigation expresses man's dynamic attempts to overcome the environmental limitations in the transformation of many of the barren areas in to the agriculture areas. The intensity of irrigation is the proportion of net irrigated area to net shown area of the aerial unit. It is an important indicator to determine the cropping pattern and agricultural productivity. The intensity of irrigation controlled by various factors such as source of irrigation, quantity and quality of water supply, intensity of network of water channels etc.

There are imbalances in irrigation development in solapur district. They are natural as well as created imbalance. The natural imbalances are caused due to the relative advantages and disadvantages of regions with respect to irrigation sources. These natural differences in regions can described as regional disparities.

Table 1- Irrigation intensity in Solapur District

\begin{tabular}{|llll|}
\hline Sr. & Irrigation Intensity & No of Tahsils & Name of tahsils \\
1 & High & 3 & Pandharpur, Malshiras, Mngalwedha \\
2 & Moderate & 2 & Karmala, Barshi \\
3 & Low & 6 & Madha, S.Solapur, N.Solapur, Sangola, \\
\hline
\end{tabular}

Source:- Complied by Researcher

\section{High Intensity}

The proportion of high intensity of irrigation is observed in Malshiras $(75.02 \%)$ taluka, where canal and well irrigation has been developed during the last two decades. This has been followed by Mangalwedha (62.45\%) and Pandharpur (60.81\%). These areas captures by Bhima and Man River which has tremendously provided water for irrigation.

\section{Moderate Intensity}

Moderate irrigation intensity is observed in Karmala(49.48\%) and Barshi (38.18\%). These tahsils have also availability of water from either canals or wells for irrigation purpose.

\section{Low Intensity}

The Southeastern Southwestern and middle tahsils have recorded low intensity (below $40 \%$ ) of irrigation giving a way to rain fed agri- culture .The intensity of irrigation is very low in North Solapur (12.16\%), Akkalkot (13.32\%),South Solapur (14.57\%)and Madha (15.24\%).

\section{Agriculture Productivity}

Agricultural productivity is the interplay of a multitude of many factors, such as environmental, socio-economic and technological factors. The agricultural productivity is closely related to the per hectare yields, where as the agricultural efficiency is much more than agricultural productivity and conveys a more comprehensive meaning. Agricultural productivity is the actual performance of the land in terms of per hectare yield, where as agricultural efficiency is a ratio between the achievement in terms of agricultural production and the actual potential of the land productivity is a physical rather than a value concept and describes the changing relation between out put and one of the major inputs like land, labor, and capital.

\section{Measurement of Productivity by Kendal's Ranking Co-efficient method}

Here, the Kendal's ranking co-efficient method (1968) is used while applying this technique; seven major crops grown in all the tahsils of the district are selected. The crops have ranked in order to their yield per unit area. Then the arithmetic mean of these ranks is obtained which Kendal's called as ranking co-efficient and the same is represented cartographically. Lower the co-efficient value, higher is the productivity level of agriculture.

Three areas of agricultural productivity have been identified as shown in

$$
\begin{aligned}
& \text { Areas of high productivity. } \\
& \text { Areas of moderate productivity } \\
& \text { Areas of low productivity. }
\end{aligned}
$$

Table 2- Agriculture productivity in Solapur District (2005)

\begin{tabular}{|llll} 
Sr & $\begin{array}{l}\text { Agriculture } \\
\text { Productivity }\end{array}$ & No of tahsils & $\begin{array}{l}\text { Name of tahsils } \\
\text { 1 }\end{array}$ High \\
2 & Moderate & 5 & $\begin{array}{l}\text { Malshiras, Pandharpur, Sangola, } \\
\text { Akkalkot }\end{array}$ \\
3 & Low & 2 & $\begin{array}{l}\text { Karmala, Barshi, Mohol, S.Solapur, } \\
\text { Mangalwedha, Madha }\end{array}$ \\
\hline
\end{tabular}

Source:- Complied by Researcher

\section{Areas of high productivity}

This category is confined largely to northern and eastern part of Solapur district comprising the tahsils of South Solapur, North Solapur, Mohol, Barshi, and Karmala. The rivers in this area provide water for irrigation in Rabi Season. The river basins have fertile soils and many farmers in this area are adopting new inputs in agriculture by using. Fertilizers, machinery, improved seeds etc. All the favorable factors and human efforts have resulted into the high agricultural productivity in the region of Solapur district.

\section{Areas of Moderate productivity}

This category of productivity covers four tahsils. The co-efficient value in this area ranges from 5.5 to 6.5 . Akkalkot tahsil is quite famous for pulses cultivation. Other tahsils like Akkalkot, Sangola, Pandharpur, Malshiras have fertile soil but paucity of water for irrigation and high variability of rainfall have resulted into moderate 
agricultural productivity.

\section{Areas of low productivity}

The low productivity areas cover two tahsils where the co-efficient value is above 6.5 . The high variability of rainfall and low intensity of irrigation have led to low agricultural productivity in dry areas of the district.

\section{Co-relation between irrigation intensity \& agricultural produc- tivity}

Irrigation is backbone of agriculture in drought pore area. The choice of cropping pattern, variety crops, method of cultivation is also depend on irrigation. There are close relationship between irrigation intensity and agriculture productivity in study region. In Solapur District the positive co-relation largely ( $45.5 \%$ to district) observed in five tahsils of district. These tahsils are Pandharpur, Malshiras, Karmala, Barshi and Madha tahsils of district. It is clearly explain that the irrigation high affects on agriculture productivity in Solapur district. If irrigation area increased, the agriculture productivity also increased.

Table 3- Co-relation among irrigation intensity and agriculture productivity in Solapur District.

\begin{tabular}{|lllll|} 
Sr. & $\begin{array}{l}\text { Level of irrigation } \\
\text { and productivity }\end{array}$ & $\begin{array}{l}\text { No of } \\
\text { Tahsil }\end{array}$ & $\begin{array}{l}\% \text { to } \\
\text { total }\end{array}$ & Tahsil Name \\
\hline 1 & HI, HP & 2 & 18.2 & Pandharpur, Malshiras, \\
2 & HI, LP & 1 & 9.1 & Mangalwedha \\
3 & MI, MI & 2 & 18.2 & Karmala, Barshi, \\
4 & LI, HP & 2 & 18.2 & Sangola, Akkalkot \\
5 & LI, MP & 3 & 27.3 & S Solapur, N Solapur, Mohol \\
6 & LI, LP & 1 & 9.1 & Madha \\
\hline
\end{tabular}

Source:- Complied by Researcher.

Perfect negative co-relation observed in only in Mangalweda, Sangola and Akkalkot tahsil of district. In Sangola and Akkalkot tahsil beneficial negative co-relation observed means in these tahsil irrigation intensity low but agriculture productivity is high. This tahsil are located low rainfall region and no canal or other irrigation sources developed. But the farmers of tahsils largely used micro irrigation system, mulching system, farm level water stoverages, low water crops for cultivation (fruit crops), favorable soil for fruit cultivation, etc. so the high agriculture productivity observed.

The negative co-relation is also observed in Mangalweda tahsil. In this tahsil irrigation intensity high but agriculture productivity low because in this tahsil agriculture productivity influence by irrigation as well as socio-economic and cultural factors of district. in Mangalweda irrigation is high irrigation due to Bhima and Man River flows and Nira Right Canal provide enormous water of irrigation. But low productivity due to traditional way of farming, jawar is monoculture crop, land holding size large, low fertility due dense irrigation for sugarcane, lazy farmers.

\section{Suggestion}

Agriculture productivity largely influenced by irrigation. Today, it is necessary to increase the agriculture productivity of the region for this irrigation can be increased. To achieve the growth of irrigation is the district. Few suggestions have to be suggested to individual level, institutional level and administrative level. They are:

- Give incentives to proper propaganda of irrigation manage- ment.

- Carried out research work to achieve innovative technology and methods of water management.

- Projects should be planned at micro level as poor peasant will bethe major beneficiaries.

- Watershed development program should be scientifically planned.

- Drip irrigation, sprinkler irrigation like measures should be adopted by the people. To encourage people give incentives in proportion.

- Use media for propaganda of irrigation management.

- Raise funds on local levels to complete small watershed programs.

- Rain harvesting is essential measure in drought prone areas.

- Repairing of canals to avoid seepage essential.

- Think globally act locally, to achieve sustainable water management.

- People participation should be give vital importance.

- The fund can rise through strong co-operative sector of the district.

- Rules, regulation and charges on irrigation water should be restructured.

- Administration should take care of completion of uncompleted projects in the district.

- Set local level committees to look after the progression of small project in the area. Such committees should be co-ordinate with CEO and collect orate of the district.

\section{References}

[1] Rawat D.S. (2009) Uttar Bharat Bhoogol Patrika., 97-100.

[2] Dubey R.N. and Negi B.S. (1996) Economic Geography of India, 190.

[3] Jasbir (1974) An Agriculture Atlas of India - A Geographical Analysis, 67-69.

[4] Pawar C.T. (1989) Impact of Irrigation on Agriculture., 13

[5] Pawar C.T. (1989) Impact of Irrigation: A regional perspective.

[6] Singh Jasbir and Dhillon S.S. (2004) Agriculture Geography. $110,126,134,155,158,160$.

[7] Socio-Economic review and district Statically abstract of Solapur District (2004-05). 